\title{
Variations in interferon production by lymphocytes from patients with chronic lymphatic leukaemia
}

\author{
A. M. R. MACKENZIE ${ }^{1}$ \\ From the Virology Laboratory, Radcliffe Infirmary, Oxford
}

SYNOPSIS In a group of patients with chronic lymphatic leukaemia leucocyte cultures showed a尺 diminished capacity to synthesize interferon when compared with controls. The leucocyte culture? with the lowest capacity to synthesize interferon came from the patients with the highest peripheral $\mathrm{N}$ blood lymphocyte counts and vice versa. These results are presented as indirect evidence that T.0 lymphocytes are more competent producers of interferon than B lymphocytes.

Interferon is a protein with antivirial activity which was first described by Isaacs and Lindenman (1957). It has no action on free virus particles but renders cells incapable of supporting the growth of viruses. In general, cells produce interferon as a result of exposure to viruses, and Gresser (1961) has shown that human leucocytes synthesize interferon in vitro in response to challenge by Newcastle disease virus and Sendai virus. Human leucocytes infected with Sendai virus have been investigated as a possible source of interferon for therapeutic use (Strander and Cantell, 1966). It is probable that, of the cell types present in leucocyte cultures, the lymphocytes are the most competent producers of interferon, although monocytes produce some; polymorphonuclear leucocytes produce little or none (Lee and Ozere, 1965; Wheelock and Edelman, 1969). Leucocyte cultures from patients with chronic lymphatic leukaemia show impairment of their capacity to produce interferon (Hadházy, Gergely, Tóth, and Szegedi, 1967; Lee, Van Rooyen, and Ozere, 1969). The study reported here is an attempt to define some of the factors responsible for this deficiency.

\section{Materials and Methods}

\section{PATIENTS}

Fourteen patients between the ages of 51 and 74 with chronic lymphatic leukaemia were studied. These were all, with one exception, under the care of the Nuffield Department of Medicine, Radcliffe

'Present address: Southampton Public Health Laboratory, General Hospital, Tremona Road, Southampton S09 4XY.

Received for publication 29 June 1972.
Infirmary, Oxford. One of the patients was examined $\overparen{D}$ six times, one was examined five times, one was $\frac{\vec{C}}{\vec{D}}$ examined three times, and five were examined twice. The remaining six were each examined once.

HAEMATOLOGICAL

Peripheral blood white cell counts were performed. by a Coulter counter. Differential white cell couvis. were carried out on films stained by Leishmaris stain, counting 100 cells.

\section{CONTROL SUBJECTS}

These were members of the hospital staff and patients $\overrightarrow{\bar{O}}$ attending the outpatient department. Persons sus- 3 pected of suffering from haematological, immunological, or infective disorders were not acceptable? as controls.

VIRUSES

Sendai virus was obtained from Dr M. S. Pereira of the Virus Reference Laboratory, Central Public Health Laboratory, Colindale, London. Stocks were prepared as follows:

Approximately 1000 haemagglutinating units $\frac{7}{0}$ (HA) were inoculated into the allantoic cavity of fertile eggs. After three days' incubation the fluid $\mathcal{O}$ was harvested, centrifuged at $100000 \mathrm{~g}$ for three hours $\mathrm{N}$ at $4^{\circ} \mathrm{C}$, and resuspended in medium 199 (Glaxo Ltd) $\mathrm{N}$ containing $0.5 \%$ bovine albumin. This suspension, $\omega$ stored in ampoules at $-70^{\circ} \mathrm{C}$, was the virus stock. The titre was $4000 \mathrm{HA}$ units $/ \mathrm{ml}$ when titrated by the method of Cantell (1959).

Sindbis virus was supplied by Dr K. H. Fantes. Stocks were grown in human embryo fibroblasts and stored at $-70^{\circ}$ in ampoules. 
MEDIA

The incubation medium for the mixed leucocyte cultures consisted of Eagles medium (Burroughs Wellcome Ltd) to which was added penicillin (100 units $/ \mathrm{ml})$, streptomycin $(100 \mu \mathrm{g} / \mathrm{ml})$, calf serum $(10 \%)$, and sodium bicarbonate $(0.044 \%)$. The same medium but with $2 \%$ calf serum was used as the diluent in the interferon assay.

\section{LEUCOCYTE CULTURES}

Fifteen $\mathrm{ml}$ of heparinized whole blood was mixed with $6 \%$ dextran in a ratio of $1: 6$. The blood-dextran mixture was drawn up into a plastic syringe which was then incubated at an angle of $45^{\circ}$, nozzle uppermost, at $37^{\circ} \mathrm{C}$. After about an hour the erythrocytes had sedimented and the supernatant plasma containing the leucocytes was expelled through a bent needle into a universal container. The leucocytes were washed twice in incubation medium and resuspended to a concentration of $10^{7}$ leucocytes $/ \mathrm{ml}$. Sendai virus was added to a final concentration $100 \mathrm{HA} / \mathrm{ml}$. The cell-virus mixture was then transferred to a stoppered tube and incubated on a roller at $36^{\circ} \mathrm{C}$ for 18 hours.

After incubation the cell suspension was centrifuged at $400 \mathrm{~g}$ for 15 minutes. The supernatant was dialysed, first for 24 hours against $\mathrm{HCl} / \mathrm{KCl}$ buffer at $p \mathrm{H} 2$, and secondly against phosphate-buffered saline at $p \mathrm{H} 7.2$ for a further 24 hours. This fluid was kept at $-20^{\circ} \mathrm{C}$ until assayed for interferon.

\section{INTERFERON ASSAY}

Threefold serial dilutions of the fluids for assay were added in $1 \mathrm{ml}$ volumes to confluent human embryo lung fibroblast tissue cultures, using three tubes per dilution. The strain of cells used was derived in this laboratory. After 18 hours' incubation at $37^{\circ} \mathrm{C}$ the cell sheets were washed twice with maintenance medium. One hundred TCD 50 of Sindibis virus were then added to each tube and to three control tubes containing no interferon. When the cytopathogenic effect was $75-100 \%$ in the control tubes all the tubes were examined. Interferon titres were calculated by the method of Lee and Ozere (1965). A standard interferon preparation containing 1200 international units $/ \mathrm{ml}$ was included in each batch of titrations. The standard deviation of the assay was $0 \cdot 25 \log$ units.

\section{Results}

COMPARISON OF CULTURES FROM CHRONIC LYMPHATIC LEUKAEMIA PATIENTS WITH CONTROLS

The interferon yielded by leucocyte cultures from leukaemia patients was compared with that yielded by the controls. The results are shown in Figure 1. The mean yield of interferon from the leukaemic cultures was significantly lower than the yield from the control cultures $(P<0.01$, Wilcoxon rank test).

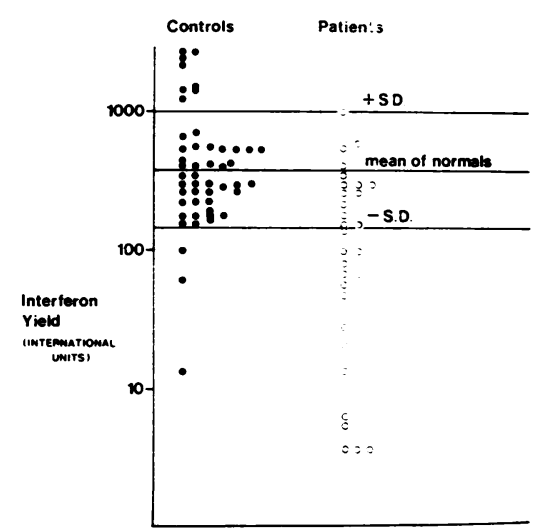

Fig. 1 Comparison of interferon yielded by leucocytes derived from chronic lymphatic leukaemic patients and from normal subjects.

CORRELATION BETWEEN PERIPHERAL BLOOD LYMPHOCYTE COUNT AND INTERFERON YIELD The relationship between the interferon yield of the leukaemic cultures and the peripheral blood lymphocyte counts of the corresponding patients is shown in Figure 2. There is a significant correlation between the peripheral blood lymphocyte count and

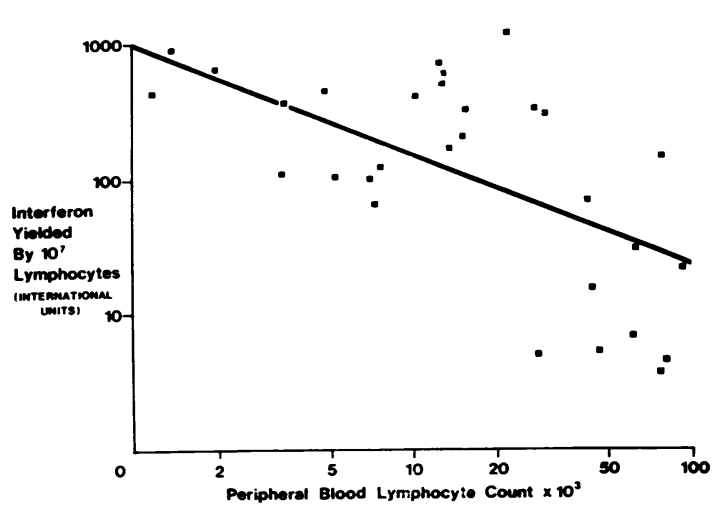

Fig. 2 Relationship between interferon yield and peripheral blood lymphocyte count in a group of patients. The interferon yielded by $10^{7}$ lymphocytes has been calculated using the differential count of the cultured blood and assuming that all the interferon is produced by lymphocytes. 
the interferon synthesizing capacity of the lymphocytes $(r=-0.64)$.

SERIAL STUDIES OF INDIVIDUAL PATIENTS Repeat cultures were prepared from eight patients who attended more than once during the course of the studies.

Patients in acute exacerbation and subsequent remission (group 1)

Three patients were in exacerbation and in need of treatment at the time of taking of their first cultures. All were treated, as a result of which there was a drop in peripheral blood lymphocyte count. As the numbers of circulating lymphocytes fell their interferon synthesizing capacity rose, eightyfold in the case of patients 1 and 2 and fortyfold in the case of patient 3 (Figs. 3 and 4, Table I).

Patients in remission (group 2)

Four patients were in clinical remission throughout the study with no significant change in peripheral blood lymphocyte count. The interferon synthesizing capacity of the lymphocytes of three of the patients (nos. 4, 5, and 6) did not change; that of the fourth (patient 7) rose fivefold, a barely significant change (Table I).

A patient in acute exacerbation not followed by remission (group 3)

This patient was treated and there was a threefold fall in peripheral blood lymphocyte count. Associated with the fall in lymphocyte count was a slight rise in interferon synthesizing capacity. There was no clinical improvement and the patient died of a chest infection three months atter the last sample was taken (Table I).

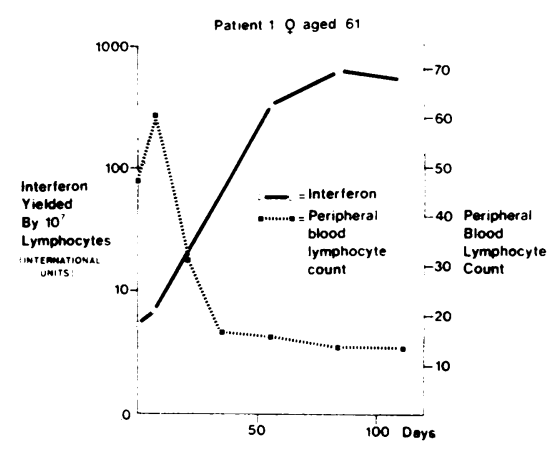

Fig. 3.

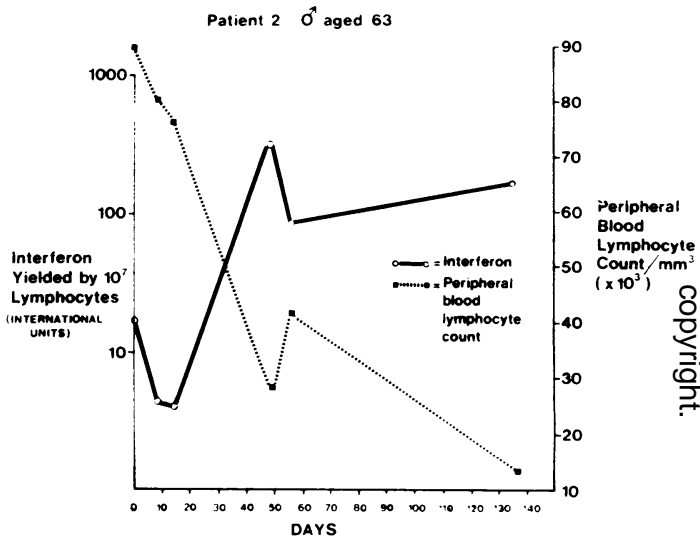

Fig. 4.

Figs. 3 and 4. Relationship in a single patient between interferon yield and peripheral blood lymphocyte count. Interferon yield calculated as in Figure 2.

\begin{tabular}{|c|c|c|c|c|c|c|}
\hline Patient No. & $A g$ & e and Sex & Group (see text) & Day of Sampling & $\begin{array}{l}\text { Interferon Yielded by } \\
10^{7} \text { Lymphocytes } \\
\text { (international units) }\end{array}$ & $\begin{array}{l}\text { Peripheral Blood } \\
\text { Lymphocyte Count } \\
\text { per } \mathrm{mm}^{3}\end{array}$ \\
\hline 3 & $\mathbf{F}$ & 65 & 1 & $\begin{array}{l}0 \\
21\end{array}$ & $\begin{array}{l}5 \cdot 1 \\
440^{5}\end{array}$ & $\begin{array}{l}28.4 \times 10^{3} \\
4.84 \times 10^{3}\end{array}$ \\
\hline 4 & $\mathbf{F}$ & 58 & 2 & $\begin{array}{l}0 \\
91\end{array}$ & $\begin{array}{l}200 \\
400\end{array}$ & $\begin{array}{l}15.5 \times 10^{3} \\
10.5 \times 10^{8}\end{array}$ \\
\hline 5 & $F$ & 68 & 2 & $\begin{array}{l}0 \\
196\end{array}$ & $\begin{array}{l}440 \\
910\end{array}$ & $\begin{array}{l}1.17 \times 10^{8} \\
1.37 \times 10^{3}\end{array}$ \\
\hline 6 & $\mathbf{F}$ & 51 & 2 & $\begin{array}{l}0 \\
7\end{array}$ & $\begin{array}{l}130 \\
100\end{array}$ & $\begin{array}{l}7.8 \times 10^{3} \\
5.4 \times 10^{3}\end{array}$ \\
\hline 7 & $\mathbf{M}$ & 56 & 2 & $\begin{array}{l}0 \\
182\end{array}$ & $\begin{array}{r}31 \\
140\end{array}$ & $\begin{array}{l}70.5 \times 10^{2} \\
84.5 \times 10^{2}\end{array}$ \\
\hline 8 & $\mathbf{F}$ & 71 & 3 & $\begin{array}{l}0 \\
6 \\
13\end{array}$ & $\begin{array}{r}290 \\
1200 \\
690\end{array}$ & $\begin{array}{l}30.6 \times 10^{3} \\
22.6 \times 10^{3} \\
12.9 \times 10^{3}\end{array}$ \\
\hline
\end{tabular}

Table I Relationship between peripheral blood lymphocyte count and interferon synthesizing capacity in six chronic lymphatic leukaemic patients 


\section{Discussion}

The results shown in Fig. 1 confirm the findings of Lee et al (1969) that leucocyte cultures from some patients with chronic iymphatic leukaemia are deficient in interferon synthesizing capacity.

Figure 2 provides evidence that in a group of patients with chronic lymphatic leukaemia, when lymphocytes are present in the circulating blood in large numbers, they tend to be deficient in their capacity to synthesize interferon. Serial study of individual patients also suggests that there is a relationship between peripheral blood lymphocyte count and lymphocyte interferon synthesizing capacity. When the number of circulating lymphocyte falls their competence to synthesize interferon rises. There is no significant change in interferon synthesizing capacity of the lymphocytes of those patients whose peripheral b!ood lymphocytes remain constant.

Lee et al (1969) stated that in their series they were unable to correlate interferon synthesizing capacity with any haematological variables, but no haematological data are given in their paper. The results reported here suggest that there is an inverse relationship between the number of circulating lymphocytes and their ability to synthesize interferon.

The existence of two populations of lymphocytes, thymus-dependent ( $T$ lymphocytes) and thymusindependent (B lymphocytes), is now widely accepted. The experiments of Wilson and Nossal (1971) indicate that in chronic lymphatic leukaemia there is a relative increase in the ratio of thymus-independent (B) lymphocytes to the thymus-dependent ( $T$ ) lymphocytes. These workers suggest that the leukaemic process involves B rather than T lymphocytes and that fluctuations in the peripheral b'ood lymphocyte count of patients reflect variations in the size of the $B$ lymphocyte population relative to a $T$ lymphocyte population of constant size. The inverse relationship reported here between peripheral blood lymphocyte count and interferon synthesizing capacity would be explained if $\mathrm{T}$ lymphocytes were more competent producers of interferon than B lymphocytes.
The findings are reported here for their possible immunological interest. The statement is often made that patients with chronic lymphatic leukaemia are particularly susceptible to certain virus infections (Wintrobe, 1967). It must be emphasized that the figures given in this paper refer to the interferon synthesizing capacity of a constant number of cells. There is no evidence that there is any impairment of the capacity of the whole patient to produce interferon and calculation shows that in those patients with high peripheral blood lymphocyte counts the diminished interferon synthesizing capacity of the cells would be compensated for by the large numbers of cells present. It would therefore be incautious to regard these results as providing an explanation for any supposed increase in susceptibility to virus diseases.

The author wishes to thank Dr S. T. Callender and Dr P. Emerson for permission to study these cases, and Dr F. O. MacCallum and Professor P. Beeson for advice throughout the work.

\section{References}

Cantell, K. (1959). Investigations on mumps virus. Propagation of mumps virus in chick embryos during serial allantoic passages with undiluted inocula. Ann. Med.exp. Fenn., 37 Suppl. 1.

Gresser, I. (1961). Production of interferon by suspensions of human leucocytes. Proc. Soc. exp. biol. (N.Y.), 108, 799-803.

Hadházy, G., Gergely, L., Tóth, F. D., and Szegedi, G. (1967). Comparative study on the interferon production by the leukocytes of healthy and leukaemic subjects. Acta microbiol. hung., 14, 391-397.

Isaacs, A., and Lindenmann, J. (1957). Virus interference. I. The interferon. Proc. roy. Soc. B., 147, 258-267.

Lee, S. H. S., and Ozere, R. L. (1965). Production of interferon by human mononuclear leucocytes. Proc. Soc. exp. Biol. (N.Y.), 118,190-195.

Lee, S. H. S., Van Rooyen, C. E., and Ozere, R. L. (1969). Additional studies of interferon production by human leukemic leukocytes in vitro. Cancer Res., 29, 645-652.

Strander, H., and Cantell, K. (1966). Production of interferon by human leukocytes in vitro. Ann. Med. exp. Fenn., 44, 265-273.

Wheelock, E. F., and Edelman, R. (1969). Specific role of each human leukocyte type in viral infections. III. 17D yellow fever virus replication and interferon production in homogeneous leukocyte cultures treated with phytohemagglutinin. J. Immunol., 103, 429-436.

Wilson, J. D., and Nossal, G. J. V. (1971). Identification of human T. and $\mathbf{B}$. lymphocytes in normal peripheral blood and in chronic lymphocytic leukaemia. Lancet, 2, 788-791.

Wintrobe, M. M. (1967). In Clinical Hematology, 6th ed., p. 1039. Kimpton, London. 